UDC 614.8.067

DOI: 10.21668/health.risk/2017.2.04.eng

\title{
ANALYZING AND DEVELOPING CRITERIA FOR ASSESSING OCCUPATIONAL TRAUMATISM RISKS BASING ON «BEST PRACTICE CODE»*
}

\section{S.P. Levashov}

Kurgan State University, 25 Gogolya Str., Kurgan, 640669, Russian Federation

A system of managing occupational risks is now being implemented in the Russian Federation; it implies developing mechanisms of their assessment. The article presents an assessment procedure for assessing occupational traumatism risks as a part of methodology for complex occupational risks assessment. Occupational traumatism risk assessment is based on such criteria as predicted traumatism frequency caused by priority risk factors for examined groups (discrete criteria of traumatism risks) and frequency diagram depending on consequences of injuries caused by priority risk factors. They are integral criteria of traumatism risks (known as $F-N$ curves). «Best practice code» means traumatism risks levels which exist now in countries with high occupational safety.

Our research objects were cases and circumstances of traumatism occurring among such an occupational group as «drivers and operators of mobile equipment». We detected that increased risks levels occurred due to a limited number of factors from each group of variables and it, in general, corresponded to Pareto principle. We obtained a dependence of $y=c \times e^{-b x}$ type ( $F-N$ curve analogue), which described correlation between relative frequency of injuries and gravity of damage caused by them as a median of temporary disability of workers from the examined occupational group $\left(R^{2}>0,9\right)$. The obtained equations for approximating curve can be criterial in assessing injuring circumstances significance and risk levels for workers from relevant occupational groups in industry and agriculture in the Russian Federation.

Assessment results and assessing priority risks and factors causing them give a possibility to make decisions related to developing strategies, programs, techniques, and activities aimed at raising workers' safety in the examined occupational group.

Key words: occupational risk, risk factor, traumatism, risk assessment criteria, принци Pareto principle, workers' safety, best practice code.

A standard set of activities which are to be performed by any employer necessarily includes occupational risks assessment. Traumatism risk management is a vital task for a lot of industries and it is considered in works by both Russian and foreign researchers [4, 7, 9-11,
12-18, 20]. The order issued by the RF Ministry of Labor and Social Protection ${ }^{1}$ fixes the job responsibility of executives and labor protection specialists at all enterprises and organizations to perform the complete set of activities on detecting, assessing and managing oc-

(C) Levashov S.P., 2017

Sergey P. Levashov - Corresponding Member of the International Academy of Sciences, Ecology and Life Safety, Candidate of Technical Sciences, Associate professor at Ecology and Life Safety Department (email: spl57@mail.ru; tel.: +7 (3522) 23-20-92).

* The work is performed within the frameworks of the grant RFFI 14-46-00008 Theory and methodology of assessing occupational risks for workers employed at industrial enterprises in the RF.

${ }^{1}$ On fixing the Integrated job description reference book on executives, specialists, and clerks positions: section «Job descriptions of executives and labor protection specialists positions» [web-source]: The Order issued by the RF Ministry of labor and Social Protection No. 559H dated May 17, 2012. // Rossiskaya gazeta. - 2012. - June 22. - No. 141.- URL: https://rg.ru/2012/06/22/doljnosti-dok.html (date of visit June 11, 2016).

${ }^{2}$ On obligatory social insurance against industrial accidents and occupational diseases: Federal law No. 125 dated July 24, 1998. [web-source]. - URL: http://docs.cntd.ru/document/901713539 (date of visit June 23, 2016).

${ }^{3}$ Regulations on the Labor protection and Working Conditions Department of the RF Ministry of Labor and Social Protection [web-source] / fixed by the order of the RF Ministry of Labor and Social Protection No.31 dated July 25, 2012. - URL: http://www.rosmintrud.ru/docs/mintrud/salary/3 (date of visit June 11, 2016). 
cupational risks. But still a concept of occupational risks assessment in Russia hasn't been developed as a practical instrument yet.

According to the existing federal law on insurance against accidents ${ }^{2}$ and regulations on Labor Protection and Working Conditions Department and Social Insurance Fund (SIF) ${ }^{3}$ working conditions and labor protection as well as occupational risks levels are monitored in our country as per economic activity and the $\mathrm{RF}$ regions.

Organizations and/or private entrepreneurs (juridical persons) which are included into the statistical register are statistical observation objects in both cases. Statistical information provided by the SIF is used as a ground for fixing "occupational risk categories" as well as for choice on priority actions aimed at their elimination.

Methodological problems. We examined statistical data provided by the SIF Kurgan regional office for a period of 1999 to 2012; the results revealed that agricultural production was one of the most injury-prone industries both in terms of the total number of grave injuries and total number of fatalities (2160 cases). And more than $47 \%$ of all the injuries occurred in the basic occupational group 8300 "Drivers and operators of mobile equipment" [8].

The analysis results showed that causes and circumstances of injuries occurring in certain occupational groups differed significantly both from each other within a group and from those which were characteristic for agricultural production workers as a whole. This fact proves that an existing approach to occupational risks assessment basing on the information on industrial threats as per industries data is hardly relevant. And yet, analysis of reports on industrial accidents (so called $\mathrm{H}-1$ forms) revealed that injuries circumstances for a specific basic occupational group are in general rather identical.

The results of traumatism analysis and screening risk assessment on the basis of criteria given in the State Standard P 51901.23-
2012 [3] showed that risks for workers from 8300 occupational group, "Drivers and operators of mobile equipment", were extremely high. It made for the necessity to perform a detailed analysis aimed at increasing risk assessment validity.

Research goal was to give grounds for methodology of assessment criteria creation and occupational traumatism risks assessment on the example of a basic occupational group.

Data and methods. We identified and ranked priority risk factors (risk indexes) which determined high traumatism level in the course of the detailed research (Table 1).

The statistical analysis results prove a hypothesis stated in works $[1,5,6]$ that accidents and injuries caused by them are not casual events. They are the result of cause-effect interactions within "a worker - working environment" system and can therefore be predicted and prevented.

In this context, planning and implementing activities aimed at increasing workers' safety should be performed as per significance of injuries causes and consequences; "a worker - working environment" system is to be developed via improvement of elements which are relatively more significant.

We used Fault Tree ${ }^{4}$ software to assess cause-effect relations significance. We applied calculation modules system in our analysis and accomplished point estimates of probability of both the system failure as a whole (an injury itself) and intermediate events as well. We determined minimal logical expressions for calculating events probability and performed point estimates of probable emergency combinations; the paper presents the results of calculating significance of initial events and their combinations.

Criteria choice and foundation. Foreign practices prove that tools and methods used for calculating risk and its components should provide obtaining of such data which in their form are similar to parameters applied for describing threshold (criterial) values of ultimate, permis-

\footnotetext{
${ }^{4}$ Fault Tree Analysis (FTA) [web-source] // Wikipedia: the free encyclopedia. - URL: https://en.wikipedia.org/ wiki/Fault_tree_analysis (date of visit July 18, 2016)
} 
sible or acceptable risks [6].

Risk criteria determination involves choice and foundation of parameters which determine monitoring system efficiency concerning set goals. According to our research goal and recommendations given in the State Standard 51901-2002 [2] as well, we chose the following parameters as risk assessment criteria:

Table 1

Register of risks for "Drivers and operators of mobile equipment" occupational group (fragment)

\begin{tabular}{|c|c|c|c|c|c|}
\hline \multirow{2}{*}{$\begin{array}{l}\text { Accident circum- } \\
\text { stances identifier }\end{array}$} & \multirow{2}{*}{$\begin{array}{c}\text { Accident circumstances } \\
\text { denomination and } \\
\text { description }\end{array}$} & \multirow{2}{*}{$\begin{array}{l}\text { Circumstances } \\
\text { occurrence } \\
\text { probability }(L)^{*}\end{array}$} & \multicolumn{2}{|c|}{$\begin{array}{c}\text { Consequences of circumstances } \\
\text { occurrence }(I)\end{array}$} & \multirow{2}{*}{$\begin{array}{c}\text { Risk as- } \\
\text { sessment } \\
(I L)\end{array}$} \\
\hline & & & Gravity & Probability $^{* *}$ & \\
\hline \multicolumn{6}{|c|}{ Event or impact $(E)$} \\
\hline E1 & $\begin{array}{l}\text { Pinching by objects or } \\
\text { between objects }\end{array}$ & 0,27 & $\begin{array}{l}\text { Lethal } \\
\text { grave } \\
\text { mild }\end{array}$ & $\begin{array}{l}0,0570 \\
0,0976 \\
0,8454\end{array}$ & $\begin{array}{l}0,01539 \\
0,02635 \\
0,22826\end{array}$ \\
\hline E2 & Fall of an injured & 0,25 & $\begin{array}{l}\text { Lethal } \\
\text { grave } \\
\text { mild }\end{array}$ & $\begin{array}{l}0,0137 \\
0,0747 \\
0,9116 \\
\end{array}$ & $\begin{array}{l}0,00343 \\
0,01868 \\
0,22790 \\
\end{array}$ \\
\hline E3 & $\begin{array}{l}\text { Contact injures or colli- } \\
\text { sions }\end{array}$ & 0,19 & $\begin{array}{l}\text { Lethal } \\
\text { grave } \\
\text { mild }\end{array}$ & $\begin{array}{l}0,0372 \\
0,0705 \\
0,8923\end{array}$ & $\begin{array}{l}0,00707 \\
0,01340 \\
0,16954 \\
\end{array}$ \\
\hline \multicolumn{6}{|c|}{ Injury source $(S)$} \\
\hline S1 & $\begin{array}{l}\text { Machines and mecha- } \\
\text { nisms }\end{array}$ & 0,28 & $\begin{array}{l}\text { Lethal } \\
\text { grave } \\
\text { mild }\end{array}$ & $\begin{array}{l}0,0427 \\
0,0843 \\
0,8730 \\
\end{array}$ & $\begin{array}{l}0,01196 \\
0,02360 \\
0,24444 \\
\end{array}$ \\
\hline S2 & $\begin{array}{l}\text { A worker's actions or } \\
\text { movement }\end{array}$ & 0,18 & $\begin{array}{l}\text { Lethal } \\
\text { grave } \\
\text { mild }\end{array}$ & $\begin{array}{l}0,0192 \\
0,0652 \\
0,9156 \\
\end{array}$ & $\begin{array}{l}0,00346 \\
0,01174 \\
0,16481 \\
\end{array}$ \\
\hline S3 & Vehicles & 0,16 & $\begin{array}{l}\text { Lethal } \\
\text { grave } \\
\text { mild }\end{array}$ & $\begin{array}{l}0,0504 \\
0,0817 \\
0,8679 \\
\end{array}$ & $\begin{array}{l}0,00806 \\
0,01307 \\
0,13886 \\
\end{array}$ \\
\hline \multicolumn{6}{|c|}{ Injury type $(T)$} \\
\hline T1 & Open wounds & 0,28 & $\begin{array}{l}\text { Lethal } \\
\text { grave } \\
\text { mild }\end{array}$ & $\begin{array}{l}0,0327 \\
0,1176 \\
0,8497\end{array}$ & $\begin{array}{l}0,00916 \\
0,03293 \\
0,23792 \\
\end{array}$ \\
\hline $\mathrm{T} 2$ & $\begin{array}{l}\text { Subcutaneous wounds and } \\
\text { injuries (pinching) }\end{array}$ & 0,28 & $\begin{array}{l}\text { Lethal } \\
\text { grave } \\
\text { mild }\end{array}$ & $\begin{array}{c}0 \\
0,1778 \\
0,8222\end{array}$ & $\begin{array}{c}0 \\
0,04978 \\
0,23022 \\
\end{array}$ \\
\hline T3 & Fractures & 0,19 & $\begin{array}{l}\text { Lethal } \\
\text { grave } \\
\text { mild }\end{array}$ & $\begin{array}{l}0,0592 \\
0,2368 \\
0,7040\end{array}$ & $\begin{array}{l}0,01125 \\
0,04499 \\
0,13376 \\
\end{array}$ \\
\hline \multicolumn{6}{|c|}{ Body part (B) } \\
\hline B1 & Upper extremities & 0,37 & $\begin{array}{l}\text { Lethal } \\
\text { grave } \\
\text { mild }\end{array}$ & $\begin{array}{l}0,0036 \\
0,0357 \\
0,9607\end{array}$ & $\begin{array}{l}0,00133 \\
0,01321 \\
0,35546 \\
\end{array}$ \\
\hline $\mathrm{B} 2$ & Lower extremities & 0,25 & $\begin{array}{l}\text { Lethal } \\
\text { grave } \\
\text { mild }\end{array}$ & $\begin{array}{c}0 \\
0,0859 \\
0,9141 \\
\end{array}$ & $\begin{array}{c}0 \\
0,02148 \\
0,22853 \\
\end{array}$ \\
\hline B3 & Head & 0,12 & $\begin{array}{l}\text { Lethal } \\
\text { grave } \\
\text { mild }\end{array}$ & $\begin{array}{l}0,0536 \\
0,0804 \\
0,8661 \\
\end{array}$ & $\begin{array}{l}0,00643 \\
0,00965 \\
0,10393 \\
\end{array}$ \\
\hline
\end{tabular}

Note:

* - as a share of the total number of accidents with occupational group representatives;

** - as a share of the total number of accidents caused by such circumstances. 
a) a predictable frequency of injuries caused by priority risk factors for workers from the examined occupational group (discrete criteria of injuries risks);

b) frequency diagrams depending on consequences of injuries caused by priority risk factors (integral criteria of injuries risks known as $F-N$ curves).

Risk evaluation is a process of comparing an evaluated risk with these risk criteria in order to determine its significance. Here we check if a risk in this situation is greater than an acceptable one which is considered to be permissible within the existing social values. Absence of occupational traumatism risks criteria in the $\mathrm{RF}$ legal regulations as well as absence of analytical tools to calculate such risks made it necessary to use relevant analogues from foreign practices as evaluation criteria.

«Best practice code» («Best practical solution») is a tool which provides practical means and relevant examples from the best domestic or foreign practices. In our context we accepted traumatism risk levels which exist now in countries with high occupational safety as a «Best practice code». "Relevance presumption" principle implies that risks which are acceptable for similar occupations, operations, production processes or activities, can be used as a standard, that is, relevant known risk values are used as criteria.

As traumatism levels in the RF are multiply higher than those existing in the EU countries and the USA, we chose traumatism parameters in the US agricultural sector as "best practice code" (Figure 1).

Our choice was determined by the fact that information resources of the US Bureau of Labor Statistics which contain more than 20 million entries are a systematized database on accidents for a period of time starting with 1992 and up to present. The data are given on the official web-site of The US National Institute for Occupational Safety and Health ${ }^{5}$.

"Agricultural equipment operators" occupational subgroup 45-2091 was chosen as an ana- logue for our Russian "Drivers and operators of mobile equipment" occupational group. As per data provided by the US Bureau of Labor Statistics, this group consisted of 221.32 thousand workers over 2004-2013; number of non-lethal injuries over the same period amounted to 5,540. 122 people died.

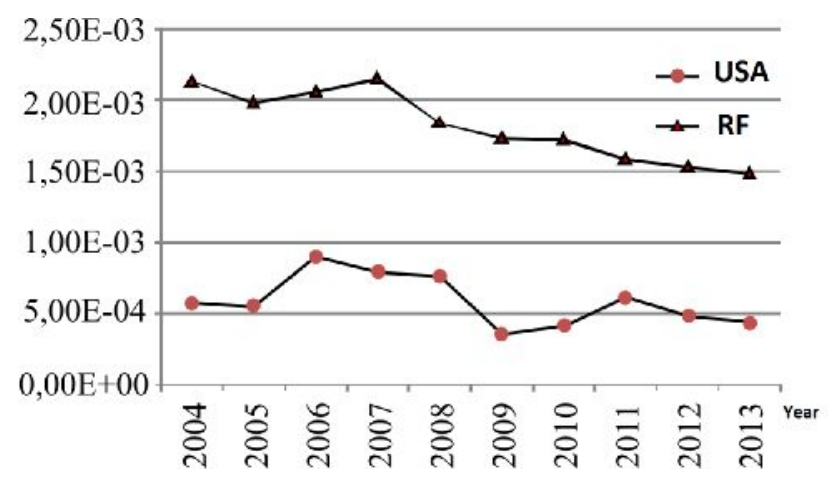

Figure 1. Non-lethal traumatism risks dynamics in agriculture

Analysis of injuries conditions and circumstances. Elimination of causes which make for or directly lead to accidents is one of the most important elements of risk management. To identify dangers related to occupational activities of injured we analyzed injuries circumstances as per methodology presented in [5]. traumatism dynamics analysis revealed that over 2004-2013 fluctuations in per cent distribution (share) of injuries caused by or related to specific factors were insignificant as they were within confidence interval boundaries $(\mu \pm 2 \sigma)$. It provided a possibility to perform statistical analysis to determine and rank priority variables/injury circumstances for workers form this occupational group.

Determination of injuries risks discrete criteria. Data on number of workers in the examined occupational group and on a number of accidents made it possible to evaluate injuries risks level.

Risks were evaluated as ratio of a number of injured workers from the "Agricultural

\footnotetext{
${ }^{5}$ The National Institute for Occupational Safety and Health (NIOSH) [web-source] // Centers for Disease Control and Prevention. - URL: http://www.cdc.gov/niosh/ (date of visit August 15, 2015).
} 
equipment operators" occupational group $(n)$ to the total number of workers in this occupational group $(N)$ :

$$
R=n / N \text {. }
$$

Non-lethal injuries risks analysis in the RF over 2004-2013 (see Figure 1) revealed that the observed descending trend of these parameters was within confidence interval boundaries $(\mu \pm$
$2 \sigma)$. This regularity was detected for the whole examined set of circumstances and conditions, that is, as per injury character; as per localization of an injury on a body; as per injury source as well as per impact type (accident type). The results of the performed analysis are shown in Figure 2.

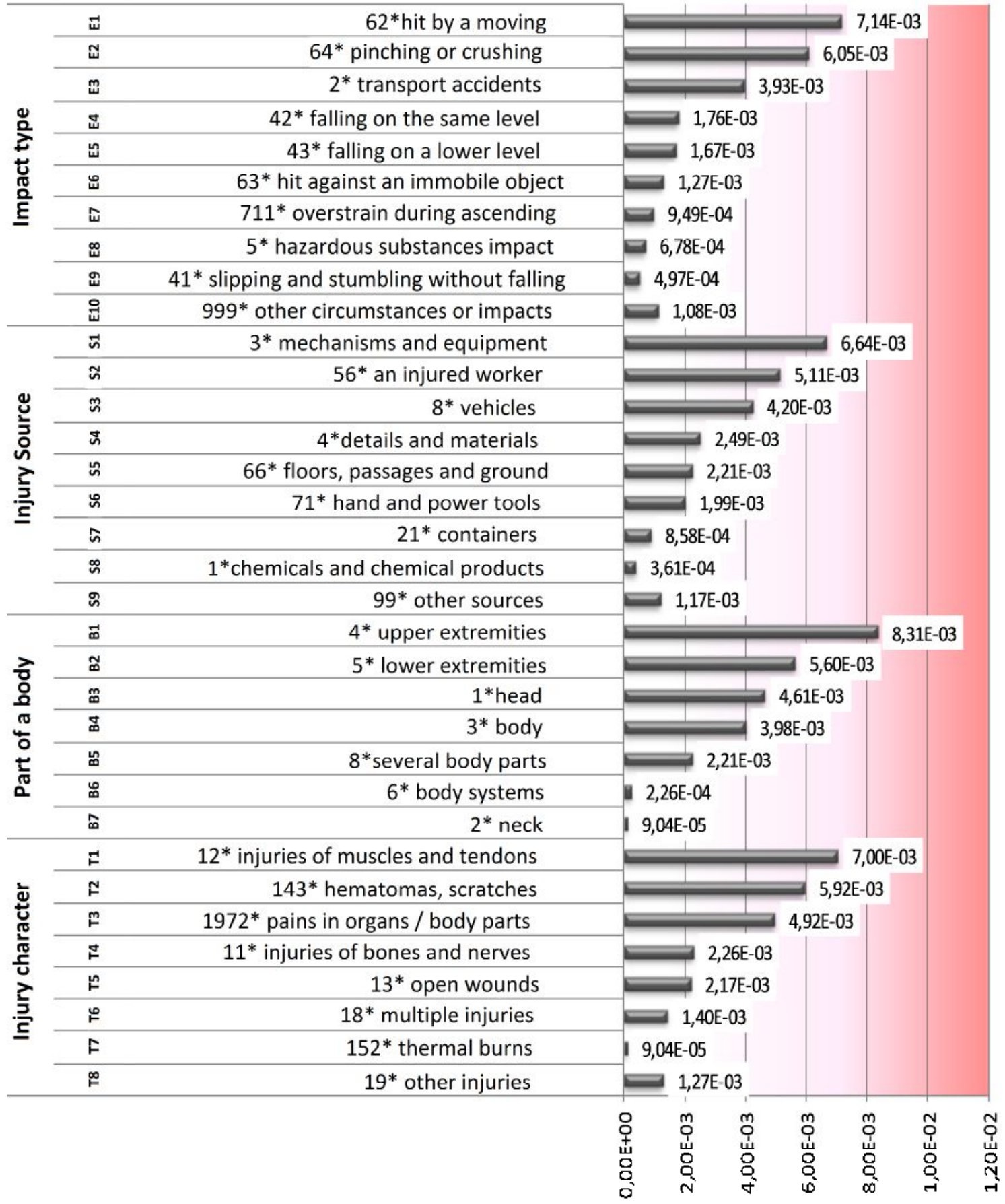

Figure 2. Non-lethal injuries risks 
2-3 factors from each group of variables are in increased risks zone which on the whole corresponds to Pareto principle: $20 \%$ means which are required to solve a problem completely, help to solve $80 \%$ of it. It seems obvious that it is those risks which are priority ones in decision-making on strategies and measures aimed at increasing safety of workers in the analyzed occupational group. Basing on traumatism levels comparison, we can state that quantitative risks values in the US agricultural sector are criterial when workers safety for analogical occupations in the RF is assessed.

Analysis of discrete traumatism risks levels allows to evaluate an injury probability without taking their consequences gravity into account. But still data on damage gravity are most significant in developing injuries prevention strategies as they most adequately highlight priority trends in increasing workers' safety.

Determination o injuries risks integral criteria. According to «OIICS Guidelines» [19], a number of days during which a worker

was temporarily disabled is one of the basic parameters indicating injury consequences gravity applied in the US. There are the following gradations: 1 day; 2 days; 3-5 days; 6-10 days; 11-20 days; 21-30 days; 31 days and longer, but not more than 3 months.

Figure 3 shows data on temporary disability duration distribution for workers from "Agricultural equipment operators" occupational group over 2004-2013. The results of statistical functions calculations are given in Table 2.

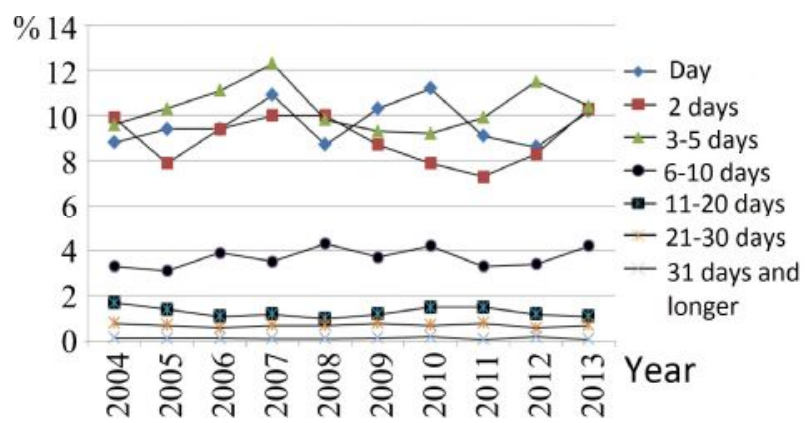

Figure 3. Temporary disability duration distribution

Table 2

Statistical functions

\begin{tabular}{|l|c|c|c|c|c|c|c|}
\hline \multirow{2}{*}{ Statistical function } & \multicolumn{7}{|c|}{ Disability duration distribution, \% } \\
\cline { 2 - 9 } & day & 2 days & $3-5$ days & $6-10$ days & 11-20 days & $21-30$ days & $\begin{array}{c}31 \text { days and } \\
\text { longer }\end{array}$ \\
\hline Median & 14,1 & 11,1 & 10,3 & 3,7 & 1,3 & 0,7 & 0,1 \\
\hline Mean deviation & 0,90 & 1,58 & 0,78 & 0,37 & 0,19 & 0,06 & 0,01 \\
\hline Standard deviation & 1,10 & 1,85 & 1,01 & 0,43 & 0,23 & 0,07 & 0,01 \\
\hline
\end{tabular}

Data analysis revealed that over the whole observation period distribution of consequences gravity probabilities $N_{i}$ was within the boundaries of confidence interval $N \pm 2 \sqrt{N}$. It makes for statistical research possibility assuming that injury distribution $N$ with certain consequences gravity $i$ remains unchanged, that is, $N_{i}=$ const with probability equal to $95 \%$.

To obtain approximating curve equation in an analytical form and to evaluate validity of the performed approximation with Excel tools, we accomplished regression analysis of the obtained data. When fitting a trend line, Excel automatically calculates $R^{2}$ value which characterizes approximation validity.
$R^{2}$ as approximation validity value is determined as per formula

$$
R^{2}=1-\frac{\sum\left(y_{i}-\hat{y}_{i}\right)^{2}}{\sum\left(y_{i}-\bar{y}\right)^{2}},
$$

where $y_{i}$ are actual values; $\hat{y}_{i}$ are approximating functions value.

The results showed that maximum value of approximation validity $R^{2}=0.9267$ corresponded to exponential distribution

$$
y=c e^{-b x}
$$

Frequency distribution median and approximating curve $y=0,5449 e^{-0,761 x}$ are given on Figure 4. 


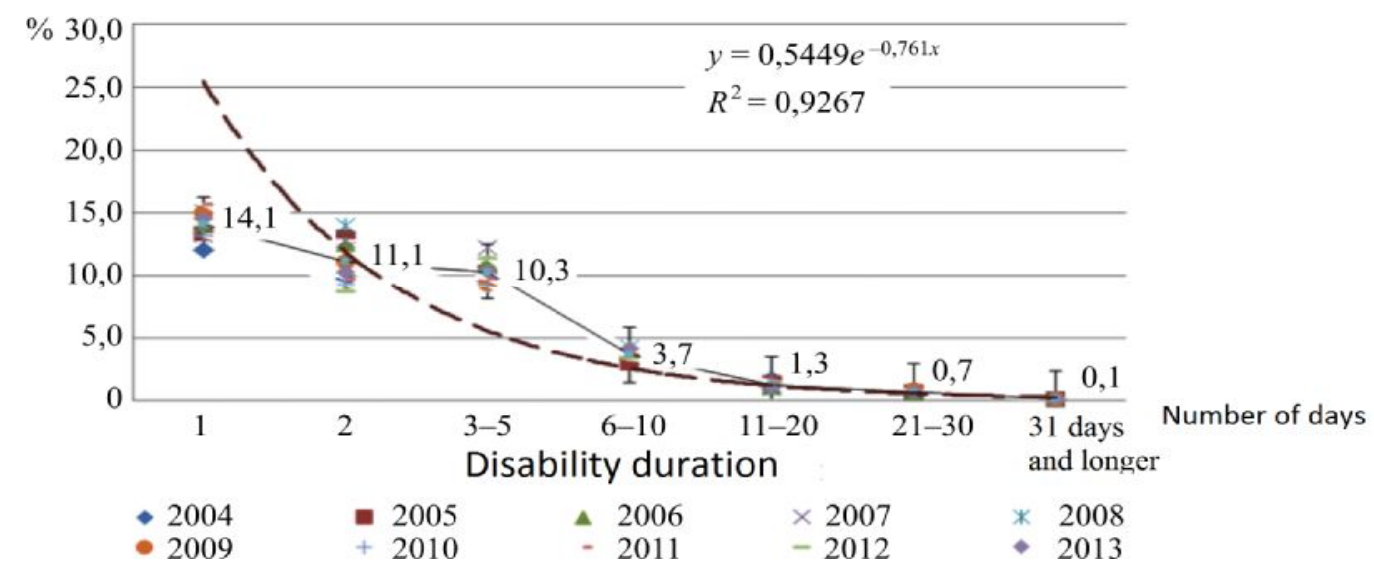

Figure 4. Correlation between relative injuries frequency and damage gravity

Table 3

Approximation curves equations

\begin{tabular}{|c|c|c|}
\hline Injury circumstances & Approximation curve equation & $\begin{array}{c}\text { Model determination } \\
\text { coefficient } \\
\left(R^{2}, p<0.05\right)\end{array}$ \\
\hline \multicolumn{3}{|c|}{ Injury character } \\
\hline Injuries of muscles and tendons & $y=0,4412 e^{-0,714 x}$ & 0,9212 \\
\hline Hematomas and scratches & $y=1,039 e^{-0,938 x}$ & 0,9605 \\
\hline Pains in organs and body parts & $y=0,5408 e^{-0,769 x}$ & 0,9542 \\
\hline \multicolumn{3}{|c|}{ Part of a body (organ) } \\
\hline Upper extremities injuries & $y=1,039 e^{-0,93 x}$ & 0,9600 \\
\hline Lower extremities injuries & $y=0,3822 e^{-0,68 x}$ & 0,9380 \\
\hline Head injuries & $y=1,4928 e^{-1,06 x}$ & 0,9785 \\
\hline \multicolumn{3}{|c|}{ Injury source } \\
\hline Mechanisms and equipment & $y=0,4857 e^{-0,732 x}$ & 0,9427 \\
\hline Injured worker & $y=0,540 e^{-0,76 x}$ & 0,9540 \\
\hline Vehicles & $y=0,3915 e^{-0,689 x}$ & 0,9421 \\
\hline \multicolumn{3}{|c|}{ Event or impact } \\
\hline Hit by a moving object & $y=0,7288 e^{-0,835 x}$ & 0,9623 \\
\hline Pinching or crushing & $y=1,1683 e^{-0,969 x}$ & 0,9575 \\
\hline Transport accidents & $y=0,3701 e^{-0,679 x}$ & 0,9410 \\
\hline
\end{tabular}

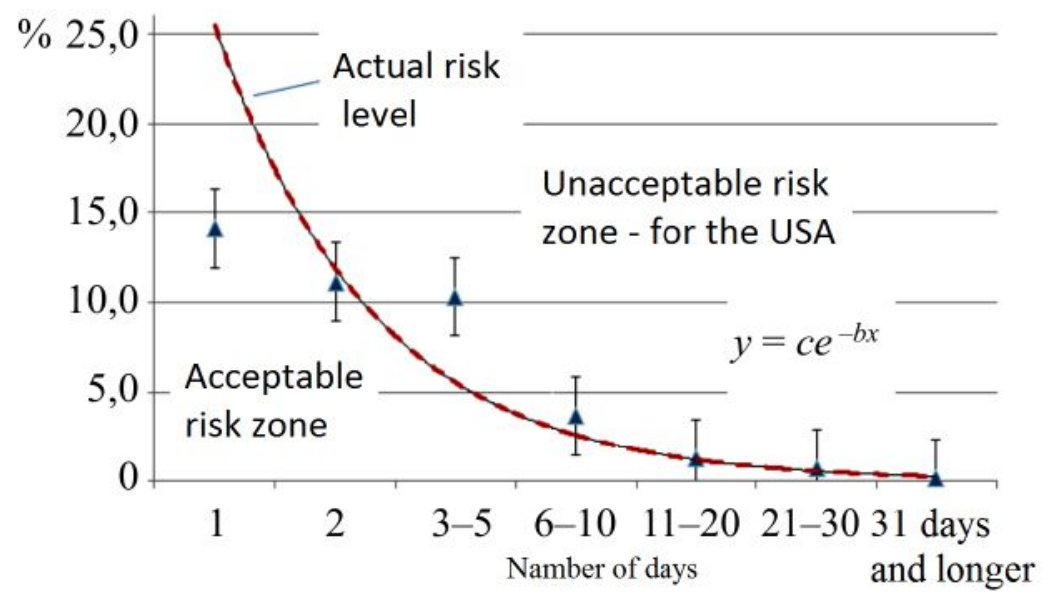

Figure 5. Correlation between relative frequency of injury circumstances and damage gravity 
The obtained dependence is in its essence an analogue of a well-known $\mathrm{F}-\mathrm{N}$-curve, which represents a graphic interpretation of correlation between an event probability and gravity. In this case the curve shows correlation between relative injuries frequency (as a \% of total number of cases) and gravity of damage caused by them (as disability duration median / period) for workers from "Agricultural equipment operators" occupational group.

Injuries risks level $(R)$ can be given as:

$$
R=f(F, N),
$$

where $F$ are discrete frequencies of accidents which caused disability days, $N$ is gravity of the given accidents consequences.

We obtained similar dependences for all detected priority risk factors during our research. Integral risk levels as per most significant injury circumstances are given in Table 3 .

So, allowing for multiply higher injury risks for workers employed at the RF agricultural enterprises (see Figure 2), we can state that $y=c e^{-b x}$ curves based on the long-term statistical observation of workers from relevant occupational groups in the USA can be used as criterial ones in evaluating acceptability of relevant injury circumstances and risk levels (Figure 5).

Conclusions. According to our research goal we took predictable frequency of injuries caused by priority risk factors for workers from the examined occupational group (discrete injuries risks criteria) and frequency diagrams depending on consequences of injuries caused by priority risk factors (integral injuries risks criteria known as $F-N$ curves) as criteria of occupational traumatism risks evaluation.

We detected that increased risks levels were caused by a limited number of factors from each group of variables which in general corresponded to Pareto principle: $20 \%$ means which are required to solve a problem completely, help to solve $80 \%$ of it.

"Relevance presumption" principle implies that risks which are acceptable for similar occupations, operations, production processes or activities, can be used as a standard, that is, relevant known risk values are used as criteria. As traumatism levels in the RF are multiply higher than those existing in the EU countries and the USA, and there aren't any standard values for occupational traumatism risks existing in the RF, we chose traumatism parameters in the US agricultural sector as a standard value.

The $y=c e^{-b x}$ dependence obtained in the course of our research is an analogue of a wellknown $F-N$-curve which shows correlation between an accident probability and gravity. In our case the curve shows correlation between relative injuries frequency and gravity of damage caused by them as a disability duration median for workers from the examined occupational group.

The research results and the approximation validity values $R^{2}>0.9$ which we obtained via regression analysis prove that the detected $y=c e^{-b x}$ dependence adequately reflects the essence of cause and effect relations between injury circumstances and consequences they have. Hence, the obtained approximating curve equations can be criterial in evaluating injury circumstances significance and risks for workers from relevant occupational groups in the RF industry and agriculture.

Results of priority risks evaluation as well as assessment of factors which determine them make it possible to take decisions related to development of strategies, programs, methods and means for increasing safety of workers from an analyzed occupational group.

\section{References}

1. Lomov O.P., Akhmetzyanov I.M., Greben'kov S.V., Levashov S.P., Terent'ev L.P. Gigienicheskie normativy. Fizicheskie faktory okruzhayushchei i proizvodstvennoi sredy: Kollektivnaya monografiya [Hygienic standards. Physical factors of the environment and occupational environment: Collective monograph]. In: O.P. Lomov ed. St. Petersburg, Professional Publ., 2013, 796 p. (in Russian). 
2. Menedzhment riska. Analiz riska tekhnologicheskikh sistem: Gosudarstvennyi standart Rossiiskoi Federatsii [Risk management. Risk analysis of technological systems: The RF State Standard 51901.1-2002.]. Available at: http: //docs.cntd.ru/document/1200030153 (22.03.2016) (in Russian).

3. Menedzhment riska. Reestr riska. Rukovodstvo po otsenke riska opasnykh sobytii dlya vklyucheniya $\mathrm{v}$ reestr riska [Risk management. Risk register. Guide on assessment of hazards risk for inclusion in risk register: The RF National Standard 51901.23-2012]. Available at: http: //docs.cntd.ru/document/1200100076 (22.03.2016) (in Russian).

4. Artem'ev V.B., Kilin A.B., Shapovalenko G.N., Osharov A.V., Radionov S.N., Kravchuk I.L. Kontseptsiya operezhayushchego kontrolya kak sredstva sushchestvennogo snizhe-niya travmatizma [Predictive control concept as a mean of substantial traumatism lowering]. Ugol', 2013, no. 5, pp. 82-85 (in Russian).

5. Levashov S.P. Manilo I.I. Otsenka riskov professional'nogo travmatizma [Occupational traumatism risk assessment]. Chelovek i trud, 2013, no. 11-12, pp. 62-70 (in Russian).

6. Levashov S.P., Shkrabak V.S. Professional'nyi risk: metodologiya monitoring i analiza [Occupational risk: Monitoring and analysis methodology]. In: V.S. Shkrabak ed. Kurgan, Izdatel'stvo Kurganskogo gosudarstvennogo universiteta Publ., 2015, 308 p. (in Russian).

7. Lisovskii V.V., Grishin V.Yu., Kravchuk I.L., Galkin A.V. Ob operativnom upravlenii riskami travmirovaniya personala: uderzhanie opasnoi proizvodstvennoi situatsii na priemlemom urovne riska [On operative managing risks of workers' traumatism: keeping a dangerous production situation at an acceptable risk level]. Ugol', 2013, no. 11, pp. 46-52 (in Russian).

8. Obshcherossiiskii klassifikator zanyatii [Russian Classification of Occupations 010-2014 (MSKZ-08)]. Available at: URL: http: //docs.cntd.ru/document/1200121893 (24.04.2016) (in Russian).

9. Pustovit A.E., Kozlov V.I. Prognozirovanie travmatizma sredi shakhterov posredstvom analiza riskov travmirovaniya [Miners traumatism forecasting by means of injury risk analysis]. Sibbezopasnost'Spassib, 2013, no. 1, pp. 234-238 (in Russian).

10. Sevast'yanov B.V., Shadrin R.O. Prognozirovanie riskov travmirovaniya rabotayushchikh v munitsipal'nykh obrazovaniyakh Udmurtskoi respubliki [Prediction of injury risks to workers employed in municipalities of the Udmurt Republic]. Problemy prognozirovaniya, 2012, no. 1, pp. 152-157 (in Russian).

11. Selivanov L.K. Otsenka riska travmirovaniya v Rossiiskoi Federatsii i federal'nykh okrugakh [Assessment of the risk of injury in the Russian Federation and federal districts]. Aktual'nye problemy aviatsii i kosmonavtiki, 2016, vol. 1, no. 12, pp. 975-977 (in Russian).

12. Suvorov S.B. Strukturirovanie riskov travmirovaniya na rabochikh mestakh [Structuring risks of traumatizing at working places]. Izvestiya vysshikh uchebnykh zavedenii. Gornyi zhurnal, 2007, no. 5, pp. 4244 (in Russian).

13. Susoeva I.V., Bukalov G.K., Repin V.M. Metod otsenki riska travmirovaniya s uchetom ushcherba na tekstil'nom predpriyatii [The Method of Estimation of Traumatizing Risks Taking into Account Damages at Textile Enterprises]. Izvestiya vysshikh uchebnykh zavedenii. Tekhnologiya tekstil'noi promyshlennosti, 2012, vol. 338, no. 2, pp. 137-141 (in Russian).

14. Feyer A., Williamson A.W. A Classification System for Causes of Occupational Accidents for Use In Preventive Strategies. Scand. J. Work Environ. Health, 1997, vol. 17, pp. 302-311.

15. Jovanović D., Bašić S., Mitrović J. Injury risk to young car drivers in traffic on territory of Republic of Serbia. Transport Problems, 2010, vol. 5, no. 2, pp. 21-30.

16. Leigh J.P., Du J., McCurdy S. A. An estimate of the U.S. government's undercount of nonfatal occupational injuries and illnesses in agriculture. Annals of Epidemiology, 2014, vol. 24, no. 4, pp. 254259.

17. Mitropoulos P., Namboodiri M. New method for measuring the safety risk of construction activities: task demand assessment. Journal of Construction Engineering and Management, 2011, vol. 137, no. 1, pp. 30-38.

18. Mosher G.A., Keren N. Analysis of safety decision-making data using event tree analysis. The Association of Technology, Management, and Applied Engineering: Conference Proceedings Papers, 2011, pp. 137-142. 
19. Occupational Injury and Illness Classification System. Centers for Disease Control and Prevention. Available at: http: //wwwn.cdc.gov/wisards/oiics/Trees/MultiTree.aspx?Year=2012 (12.02.2016).

20. Schaufler D.H., Yoder A.M., Murphy D.J., Schwab C.V., Dehart A.F. Safety and health in onfarm biomass production and processing. Journal of Agricultural Safety and Health, 2014, vol. 20, no. 4, pp. 283-299.

Levashov S.P. Analyzing and developing criteria for assessing occupational traumatism risks basing on «Best Practice Code». Health Risk Analysis, 2017, no. 2, pp. 35-44. DOI: 10.21668/health.risk/2017.2.04.eng

Received: 12.02 .2017

Accepted: 20.05.2017

Published: 30.06.2017 